\title{
EXPLORING THE SATISFACTION AND DISSATISFACTION FACTORS DERIVED FROM FOOD AND BEVERAGE SERVICES OF THERMAL HOTELS
}

\author{
Ozan KAYA ${ }^{\mathrm{a}}$ \\ aAssistant Professor, Mugla Sitki Kocman University, 48600, Mugla, Turkey, ozankaya@mu.edu.tr \\ Cite this article: Kaya, O. (2018). Exploring the Satisfaction and Dissatisfaction Factors Derived from Food and \\ Beverage Services of Thermal Hotels. Deturope, 10(3), 143-161.
}

\begin{abstract}
The increase in supply and demand in thermal tourism has led to the intensification of competition. This situation causes the thermal hotels to spend more effort on issues such as understanding customer expectations and providing customer satisfaction. Food and beverage services have great importance in all areas of tourism as well as in thermal hotels. Thus, the main purpose of the study is to reveal the factors affecting the tourists' satisfaction or dissatisfaction in food and beverage services in thermal hotels. The research was conducted in thermal hotels in Denizli, Turkey. Tourists' online reviews on TripAdvisor were analysed by content analysis. The findings clearly show the main areas of satisfaction of the food and beverage services in the thermal hotels as taste of food, employees, quality of food and activities in the restaurants. However, the main areas where the online reviewers are dissatisfied are high price, variety of food, capacity for restaurants and freshness of food. Then, one-way ANOVA was performed to determine whether satisfaction levels of food and beverage service has an affect on overall hotel performance in the different categories of review. Results show the strong relationship between customers' satisfaction on food and beverage services and overall thermal hotel satisfaction.

The abstract of this study was presented in Cultural Management and Governance for European Thermal Tourism: Creativity and Innovation for cultural and tourism management in European Thermal Routes and Sites Conference, Cori, Italy, 6 November 2017.
\end{abstract}

Keywords: thermal tourism, tourist satisfaction, food and beverage services, online review.

\section{INTRODUCTION}

The rising tendency in global tourism demand and revenues has led to developed and developing countries to take tourism into their agenda to receive more tourists and tourism income. Similarly, today's tourism professionals also focus on alternative types of tourism by creating product diversification away from sea-sun-sand-based tourism (Kaya, 2017). Thermal tourism, which has seen significant developments throughout the world in recent years, has emerged from this situation.

Thermal springs have been used for having a healthy life for thousands of years (LaMoreaux, 2005). Today, thermal spring waters are used to treat discomforts, reduce stress levels, and maintain beauty and well-being (Erfurt-Cooper \& Cooper, 2009). Therefore, the alternative uses of thermal waters are important in today's tourism industry. To support this, there is a consensus among researchers that health and health-related tourism activities and 
tourism movements are on the rise (Harmsworth, 2004; Gligorijevic \& Petrovic, 2010; Hudson \& Li, 2012).

With the increase in the tourism demand and supply of thermal tourism, the competition has been intensified (Fontanari \& Kern, 2003). The thermal hotels offer both the services provided by the classical hotel companies and the health and special services required by thermal tourism. Especially, the types of services offered by thermal hotels and the contents of these services are very important for the thermal tourists (Lagrosen \& Lagrosen, 2016). In this respect, the increasing demand for thermal hotels and the increasing number of thermal hotels reveal the necessity of products and services that are not possible to be imitated by their competitors (Emir \& Paşaoğlu, 2013). Within this context, food and beverage (F\&B) services in thermal hotels are one of the most prominent parts for the thermal tourists due to their basic and special nutritional needs for thermal tourists' health conditions and their F\&B services expectation distinguishes from average hotel visitors (Emir \& Paşaoğlu, 2013; Giritlioglu, Jones \& Avcikurt, 2014). However, while much is known about the factors affecting tourist satisfaction in F\&B services in other hotel types (Smith \& Puczkó, 2009; Saar, 2010; Lagrosen \& Lagrosen, 2016) little is known about factors affecting thermal hotel visitors F\&B satisfaction (Giritlioglu et al., 2014). Current study aims to fill the gap in the literature by an empirical study that focused on thermal hotels F\&B services. Once the thermal hotel management knows factors affecting the tourists' satisfaction or dissatisfaction in F\&B services, the management will be able to compete with their competitors by having the opportunity to offer unique experiences to their guests. Therefore, the subsequent sections of the research are structured in conceptual framework, methodology, analysis, results and discussion, and conclusion.

\section{CONCEPTUAL FRAMEWORK}

\section{Thermal tourism}

Health and wellness tourism has become an international trend for consumers who want to increase their welfare. These tourism types cover travels to protect or enhance one's personal well-being (Stará \& Peterson, 2017). However, thermal tourism includes tourism movements that are made to use thermal waters for health, wellness, entertainment, rest, beauty etc. In this context, thermal tourism referred as a sub-sector of health tourism based on the idea of using thermal waters for health and wellbeing (Azakli, 2012). 
Nowadays, individuals participate in thermal tourism activities in order to treat various illnesses, reduce the existing stress levels and to protect their vitality (Giritlioğlu, 2013). Thermal baths and thermal tourism have a much closer relationship to environmental tourism and human health than mass tourism. In fact, thermal destinations allow places to develop locally. For this reason, thermal tourism activities lead to the development of local economies (Zollo, Simonetti, Salsano, \& Rueda-Armengot, 2015). Similarly, Araujo, Paiva, Ribeiro, \& Coutinho (2015) examine thermal tourism as a tool to contribute in the development of the regions by eliminating the inter-regional economic asymmetries. Besides the economic contribution to regions, main thermal tourism features as follows (Zengin \& Eker, 2016);

- Thermal tourism serves both ill and healthy people.

- In order to have thermal tourism in a region, it is necessary to have a thermal source.

- Thermal facilities should offer all the features in terms of technical, geological, hygienic, health and aesthetic facilities.

- Thermal tourism provides fitness, leisure, and relaxation beside healing effect.

- Thermal tourism is a tourism type that can be done for all the year round.

- Thermal tourism is a type of tourism that requires expertise.

- Thermal tourism is a high-income type of tourism.

- In thermal tourism, the length of stay depends on the healing process.

- Enterprises operating within the scope of thermal tourism have higher costs.

- Thermal tourism is a type of tourism that builds a habit in tourists.

These features of thermal tourism make it more attractive than other tourism types. In addition, the level of pressure and stress created by today's business life is causing individuals to seek relaxation opportunities. Thermal tourism is the leading option for the people who want to resist the stress of their daily life or treat certain diseases (Türksoy \& Türksoy, 2010; Giritlioğlu, 2013; Giritlioglu et al., 2014).

\section{Thermal tourism in the World and Turkey}

Tourism and hospitality are among the world's fastest growing industries (25 million tourists in 1950 and 1235 million tourists in 2016). All countries want to get higher shares from this growing market (UNWTO, 2017). Many countries in the world are popular tourism destinations not only because of their interesting landscapes and extraordinary natural scenery but also because of their natural and hot mineral thermal waters (Erfurt-Cooper \& Cooper, 2009). 
Thermal waters have been used for having a healthy life since the ancient era (Kervankıran, 2016). Today, thermal spring waters are used to treat discomforts, reduce stress levels, and maintain beauty and well-being. Contemporary life conditions make using of thermal waters more popular than in any period of the history. Therefore, the alternative uses of thermal waters are important in today's tourism industry.

There is a consensus among researchers that health and health-related tourism activities and tourism movements are on the rise. That is why demand for thermal tourism has been increasing globally for over 20 years and it is one of the fastest-growing sub-sectors of health tourism (Erfurt-Cooper \& Cooper, 2009; Kovács, Bacsi, \& Lőke, 2012; Giritlioglu et al., 2014; Costa, Quintela, \& Mendes, 2015; Kervankıran, 2016). For example, over 15 million people visit thermal destinations in Italy for health and well-being purposes. Italy reached 4 billion Euros in 2009, with more than 30,000 wellness-related enterprises in 2009 (Zollo et al., 2015). Similarly, every year more than 10 million tourists visit Germany and Hungary for thermal purposes (Kervankıran, 2016). Mainil, Eijgelaar, Klijs, Nawijn, \& Peeters (2017) noted that in 2014, 61.8 million people visited the European Union (EU) for health, spa/thermal and healthcare services as part of health tourism. Surprisingly, only four countries, namely Germany, France, Poland, Italy and Sweden share more than three-fourths of the total health tourism income (46.9 billion euros in 2014) in the EU. In addition, the global thermal and spa industry revenues reached \$ 150 billion in 2015 (Global Wellness Institute, 2017).

Developed countries have a bigger share of the thermal related touristic movement than developing countries due to their early recognition of the global trend towards thermal tourism. Turkey is a classic example of this situation. According to the Ministry of Energy and Natural Resources of Turkey (2018), Turkey is rich in geothermal energy resources. It ranks fifth in the world for geothermal heat and thermal spring applications (Kilic, 2016). Similarly, Giritlioglu et al., (2014) argue that Turkey with over one thousand hot springs is poorly developed in thermal tourism. Kervankiran (2016) points out that people who live in Turkey have traditionally used thermal spring water for health purposes since the Hittite era but the increase in investments related to thermal tourism after 2007. While the numbers of thermal hotels were 78 in 2006, with a bed capacity of 17,767, this number increased to 160 and 54,962, respectively, in 2016 (see Table 1). 
Table 1 Number of thermal hotels in Turkey

\begin{tabular}{lcccccr}
\hline & \multicolumn{2}{c}{$\mathbf{2 0 0 6}$} & \multicolumn{2}{c}{$\mathbf{2 0 1 0}$} & \multicolumn{2}{c}{$\mathbf{2 0 1 6}$} \\
& Hotel & Bed & Hotel & Bed & Hotel & \multicolumn{1}{c}{ Bed } \\
\hline Tourism Operation Licensed & 37 & 9,736 & 50 & 15,796 & 75 & 25,353 \\
Tourism Investment Licensed & $\mathbf{8}$ & 2,438 & 15 & 7,757 & 44 & 23,218 \\
Licensed by Municipality & 33 & 5,593 & 35 & 6,174 & 41 & 6,391 \\
TOTAL & $\mathbf{7 8}$ & $\mathbf{1 7 , 7 6 7}$ & $\mathbf{1 0 0}$ & $\mathbf{2 9 , 7 2 7}$ & $\mathbf{1 6 0}$ & $\mathbf{5 4 , 9 6 2}$ \\
\hline
\end{tabular}

Source: Ministry of Culture and Tourism of Turkey (2017). http://yigm.kulturturizm.gov.tr/TR,9579/turizmtesisleri.html

\section{Importance of food and beverage services in thermal hotels}

Thermal hotels have a primary role in the development of thermal tourism in a region (Boekstein, 2014). However, the increase in the demand for thermal tourism is reflected itself in the supply side of thermal hotels. As the number of thermal hotels increases, the competition among the hotels is also intensifying. This situation requires that the products and services of the thermal hotels be unique.

Thermal hotels are crucial for tourists who visit the region to get thermal services (Bakucz $\&$ Flink, 2012). Therefore, to ensure tourist satisfaction, not only thermal services but also non-thermal services should be qualified. Customer satisfaction has been an important part of marketing and management literature for decades, as satisfied customers can provide longterm benefits, including loyalty and profitability (Liu \& Jang, 2009). Consumer satisfaction is mainly the result of cognitive comparisons of product-related expectations and comparisons of business performance (Bigné, Matilla, \& Andreu, 2008). Consumer satisfaction occurs when the product's performance after use exceeds its pre-use expectations and consumer dissatisfaction if product performance is below consumer expectations (Oliver, 1980). In thermal hotels, the similar process operates in terms of tourist satisfaction (Chua, Lee, Goh, \& Han 2015).

Lebe (2006) points out the F\&B services as important as health-related services provided in thermal hotels. Similarly, Giritlioglu et al. (2014) state that thermal hotels should provide special F\&B services to their visitors to ensure successful thermal hotel experiences. Andaleeb and Conway (2006) state that department satisfactions based on each service encounter lead to overall satisfaction with the hotels. It is also apparent, that if hotel and restaurant managers really want to gain a competitive advantage, they must endeavour to provide customer satisfaction.

F\&B service is one of the critical elements in both land and sea-based tourism types (Kaya, 2017). For this reason, meeting the expectations of tourists for F\&B service in thermal hotels 
has an important role in terms of service quality and overall satisfaction. From another point of view, due to basic and special nutritional needs of thermal tourists' health conditions, F\&B services are the essential part of thermal hotels in customer satisfaction (Saar, 2010). This reveals the complementary nature of $\mathrm{F} \& \mathrm{~B}$ services in customer satisfaction.

\section{METHODOLOGY}

\section{Research objectives}

In contemporary competitive conditions, defining the customer expectations is a critical prerequisite for thermal hotels to satisfy their customer. For customer satisfaction, F \& B services have a primary role in completing health services, and meeting specific nutritional needs of customers visiting thermal hotels for health or well-being (Alén, Fraiz, \& Rufin, 2006; Giritlioglu et al., 2014). Therefore, examining tourist' F\&B service experiences in thermal hotels from online booking websites can be an effective way to obtaining valuable insight. The specific objectives of the research are:

(1) to reveal the factors affecting the tourists' satisfaction or dissatisfaction in F\&B services of thermal hotels; and

(2) to identify effects of satisfaction levels from F\&B services to overall hotel satisfaction.

\section{Data collection}

As well known, customer satisfaction or dissatisfaction arises from a comparison of consumers' after-consumption evaluation with consumers' product-related expectations (Liu \& Jang, 2009). Today, one of the most practical ways to achieve this is to check online reviews. Therefore, online travel reviews are emerging as a powerful source of information affecting tourists' pre-purchase evaluation of a hotel organization (Browning, So \& Sparks, 2013; Mauri \& Minazzi, 2013). Growing importance and effect of electronic word-of-mount (E-WOM) directs the researchers to online reviews. In addition, these reviews and ratings indicate the tourists' degree of satisfaction with the hotel or related department/s (Gretzel \& Yoo, 2008; Gu \& Ye, 2014; Schuckert, Lu, \& Law, 2015).

The data used for this research were collected from TripAdvisor. The research analysed and evaluated the travellers' reviews about the F\&B services provided by the thermal hotels on TripAdvisor. The reason for choosing TripAdvisor was that it is one of the leaders in social media travel content providing reviews of the hotel, places, and restaurants (Schuckert et al., 2015). In 2017, Trip Advisor's official page posted more than 500 million reviews and 
more than 390 million travellers were using the page (https://tripadvisor.mediaroom.com/trabout-us, 2017).

The sample of the study include 4 or 5 star thermal hotels operating in Denizli, Turkey, According to the Ministry of Culture and Tourism of the Republic of Turkey, there are one 4 star and six 5 star thermal hotels operating in Denizli (http://yigm.kulturturizm.gov.tr, 2017). All the hotels are registered with Trip Advisor, and the reviews and ratings of all F\&B services are accessible through Trip Advisor. For the research sample, 3,573 online reviews, submitted between May 2006 and September 2017, were assessed. In the translation and evaluation of reviews other than English, Turkish and German languages, assistance was obtained from professional translation agencies.

\section{Research design}

In this research, a mixed-methods design was employed to answer each research question. In a mixed-methods design, both qualitative and quantitative methods are used together (Liu, Kim, \& Penning-Gray, 2015). This method includes transformative designs (quantization process) that the qualitative data are converted (quantized) into quantitative data to use in suitable statistical techniques (Driscoll, Appiah-Yeboah, Salib, \& Rupert, 2007; Teddlie \& Tashakkori, 2009).

For data analysis four types of variables were used for evaluation; 1. Nationality, 2. Travel types, 3. Overall evaluation score for the hotel in TripAdvisor (From 1 to 5), 4. Reviews about F\&B services in the thermal hotel. In the qualitative phase of the study, following the previous studies (e.g., Stepchenkova \& Zhan, 2013; Berezan, Raab, Tanford, \& Kim, 2015; Wang \& Hung, 2015) a content analysis was employed which is a useful technique to analyse customer reviews and consumer comments (Berezan et al., 2015). Therefore, reviews on F\&B services in the thermal hotel were coded and classified under four categories to understand the relation between overall scores and F\&B review categories. These categories are 1 . No review about F\&B services, 2. Negative review about F\&B services, 3. Neutral review about F\&B services and 4. Positive review on F\&B services. Then, in the quantitative phase One-Way ANOVA test is used to determine whether there are any statistically significant differences between the means (overall hotel score) of categories.

\section{RESULTS AND DISCUSSION}

As previously mentioned, this study aims to identify the factors affecting the tourists' satisfaction or dissatisfaction in F\&B services of thermal hotels and, the effects of satisfaction 
levels from $F \& B$ services to overall hotel satisfaction. For this purpose, 3,573 online reviews were analysed in the study. Table 2 shows the nationality distribution of visitors who stayed in thermal hotels in Denizli, Turkey. As seen in Table 2 the majority of the visitors of thermal hotels are domestic visitors. However, Spain (219), USA (204), England (180) and Japan (156) are the main tourist generating countries for thermal hotels in Denizli.

Table 2 Nationality of visitors

\begin{tabular}{lrr}
\hline Nationality & n & \% \\
\hline Turkey & 1,325 & 37,1 \\
Spain & 219 & 6,1 \\
USA & 204 & 5,7 \\
England & 180 & 5,0 \\
Japan & 156 & 4,4 \\
Argentina & 144 & 4,0 \\
Italy & 132 & 3,7 \\
Australia & 125 & 3,5 \\
Russia & 85 & 2,4 \\
Germany & 78 & 2,2 \\
Not Available & 216 & 6,0 \\
Others & 709 & 19,9 \\
\hline TOTAL & $\mathbf{3 , 5 7 3}$ & $\mathbf{1 0 0}$ \\
\hline
\end{tabular}

Figure 1 shows the travel types of thermal hotel visitors. According to Figure 1, most of the visitors coming to thermal hotels travel with their families $(30.8 \%)$, couples follow this group with $27.6 \%$ and $23.6 \%$ of the visitors travel with their friends.

Figure 1 Travel types of thermal hotel visitors $(\mathrm{N}=3,573)$

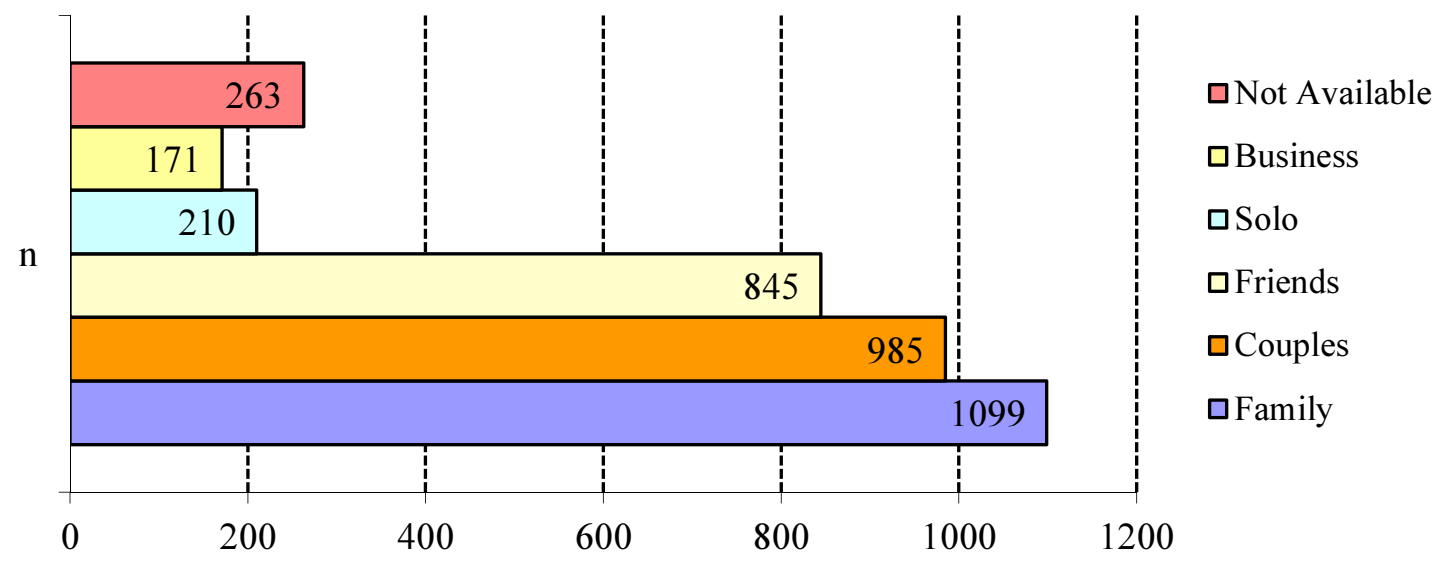

\section{Content analysis of reviews}

According to the descriptive analysis of reviews, the distribution to categories is as follows; $804(22.5 \%)$ of 3,573 reviewers did not submit any review on F\&B services, however, there are 1,013 (28.4\%) negative reviews, 355 (9.9\%) neutral reviews (e.g. restaurant was crowded but meals were tasty) and 1,401 (39.2\%) positive reviews on F\&B services in thermal hotels. 
Figure 2 shows how F\&B services are important for visitors of thermal hotels with a total of $78.5 \%$ evaluation rate. One of the purposes of the study is to reveal the factors affecting the tourists' satisfaction or dissatisfaction in F\&B services of thermal hotels. However, neutral reviews contain both positive and negative opinions about F\&B services in thermal hotels. Therefore, each positive and negative evaluation item for the F\&B services in the neutral reviews has been distributed to the positive and negative categories to identify all factors that affect tourists' satisfaction or dissatisfaction in F\&B services. Thus, positive reviews increased to 1,756 and negative reviews to 1,368 .

Figure 2 Review categories

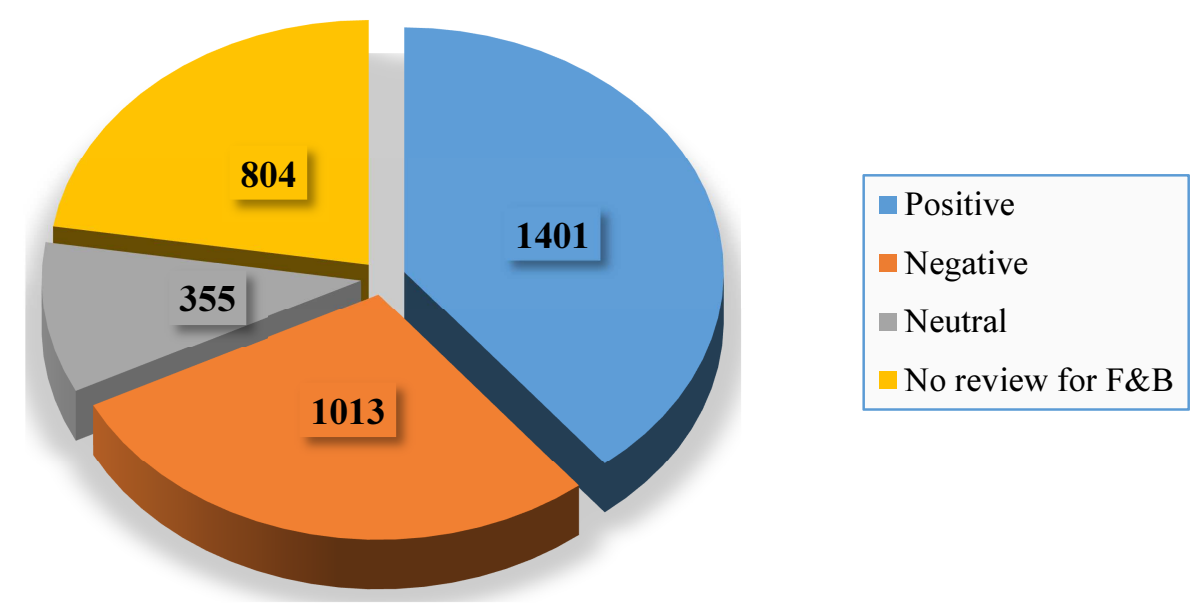

\section{Satisfaction factors}

According to the content analysis of reviews, there are four main factors affecting the tourists' satisfaction in F\&B services in thermal hotels. As seen in Table 3 these factors are taste of food, employee, quality of food, and activities in restaurants.

Table 3 Factors affecting tourist satisfaction in the services $F \& B(N=1,756)$

\begin{tabular}{lcc}
\hline Factor & $\mathbf{n}$ & $\mathbf{\% *}$ \\
\hline Taste of food & 1,258 & 71,6 \\
Employee & 812 & 46,2 \\
Quality of food & 657 & 37,4 \\
Activities in the restaurant/s & 482 & 27,4 \\
\hline
\end{tabular}

* Respondent could mention a number of responses.

Taste of food: 1,258 of 1,756 (71.6\%) of the positive reviews mentions taste of food which is a critical factor for F\&B services to satisfying both national and international tourists in the thermal hotel. Basil \& Basil (2009) also found taste as a major indicator of satisfaction in their 
research with $95 \%$ in upscale restaurants. Similarly, Clark (1998) finds that taste of food is an important factor in consumer food choice. In this research $71.6 \%$ ratio proves that taste of food is a critical factor for satisfying tourists who use F\&B services of thermal hotels. Some of the reviews are as follow;

"the evening meal was a buffet, the range was ok and the food was tasty" England, Score: 4, Travels with family.

"The service is great and the food tastes good", Thailand, Score:5, Couple.

"Food was plentiful \& good tasty meals", Turkey, Score:5, Travels with family.

"The buffet breakfast is really tasty" USA, Score: 4, Solo.

"....There is a dish I highly recommend of flat bread with spinach and cheese rolled up, so tasty ....." Canada, Score:5, Travels with family.

Employee: The importance of employees in the service sector has been known for a long time (Kuo, 2007). Many studies proved the existing direct relationship between employee or employee-related factors and customer satisfaction (Gould-Williams, 1999; Winstead, 2000; Keung, 2000). Accordingly, the employee is also revealed as a satisfaction-providing factor in F\&B services in thermal hotels. Among 1,756 positive reviews, 812 mentioned employees. Such as;

“..... brilliant staff was great and it was just a great stop over...." Australia, Score:5, Travels with friends.

“...Foods are delicious and staffs are very helpful...", Turkey, Score:5, Travels with family.

“...The restaurant staff were very helpful and very kind”, Spain, Score:4, Couple.

"Waiters in the bar were perfect, meals were delicious". Canada, Score:5, Solo.

Quality of food: Quality of food is an important success factor for both restaurants and hotels (Giritlioglu, et al., 2014). This factor can also be applied to thermal hotel F\&B services. Mela (1999) states the quality of food is an indicator of matching the consumers' expectations in restaurants. According to content analysis, 657 of 1,756 reviewers mentioned it positively.

"The hotel provide with breakfast and diner included and even this is like a buffet style, you will find there a very good quality of food with so much choices it can satisfy all the tastes", Canada, Score: 5 , friend.

"The hotel caters for large bus tours so the buffet had a good variety of food at a good quality for both the evening meal and breakfast", Australia, Score:4, Solo.

"The food was healthy and good quality", Turkey, Score:5, family.

"Food quality is very good and it makes me happy", Singapore, Score:5, Couple. 
Activities in the restaurant/s: The main motivations of visitors to thermal hotels can be considered as health, refreshment or relaxing (Kelly, 2012). However, unexpectedly, many tourists $(482$ in 1,756) were satisfied with activities in restaurants.

“...the lounge area was great with a large open fire and live music..", Ireland, Score:5, Couple. "Dinner outdoors was a perfect setting - there was a live "Turkish Pancake" Counter serving excellent pancakes! The music was soft \& soothing", India, Score:5, friends.

"Dinner for group guests was served next to cold water swimming pool, with wide variety of food, and live music from keyboard playing good old time songs from the 60s-70s", Italy, Score:4, family.

"There's live music and belly dance show after dinner", Turkey, Score: 5, Business.

\section{Dissatisfaction factors}

The factors that cause dissatisfaction with F\&B services in Thermal Hospitals were identified by content analysis in this study. In this context, four dissatisfaction factors were derived from the content analysis, including high price, variety of food, the capacity of restaurant/s, and freshness of food (Table 4).

Table 4 Factors causing tourist dissatisfaction in the F\&B services $(N=1,368)$

\begin{tabular}{lcc}
\hline Factor & $\mathbf{n}$ & $\mathbf{\% *}^{*}$ \\
\hline High price & 1,024 & 74.8 \\
Variety of food & 752 & 54.9 \\
The capacity of restaurant/s & 542 & 39.6 \\
Freshness of food & 412 & 30.1 \\
\hline
\end{tabular}

* Respondent could mention a number of responses.

High price: The effect of the price on customer preferences and satisfaction is emphasized in many researches (Hill, Roshe, \& Allen, 2007; Saraiva, Cid, \& Baião, 2011; Rahman, Kalam, Rahman, \& Abdullah, 2012; Gagić, Tešanović, \& Jovičić, 2013). Particularly, unfair priced or high priced $\mathrm{F} \& \mathrm{~B}$ affects customer satisfaction in a negative manner. In this research, during the content analysis process, it is understood that the hotels are usually operating half-board. It means that tourists pay for everything except breakfast and dinner. Especially the beverage prices of all hotels disturb visitors extremely. 1,024 of 1,368 revivers' mentioned price related comment for F\&B negatively, such as;

"Beverages were the most expensive we had come across, approx. 30\% higher than everywhere else!" Argentina, Score:2, family.

"The buffet dinner was tasty with a good quality as was breakfast but I found the drinks prices high." England, Score:3, Solo. 
"All drinks and snacks double the price as bars and cafes outside and the cheapest bottle of wine being 35 euros" Turkey, Score:3, friend.

"They are demanding cash for drinks at the pool (who carries cash to the pool??) and at crazy prices; 9 euro for a beverage." Canada, Score:2, family.

Variety of food: Variety of food in the menus suit individuals' daily life preferences in restaurants. In addition, Abbey, Wright, \& Capra (2015) stated that the power to choose from the menu increases levels of individuals' food service satisfaction up to $30 \%$. This factor not only includes the number of meals on buffet or menu but also includes alternative food options like vegetarian and dietary ones (Zhou, Ye, Pearce, \& Wu, 2014). Variety of food related reviews consists 752 of 1,368 negative reviews.

"The food menu wasn't that great ...even though they served buffet but it lacked variety!" India, Score: 2, Couple.

"The buffet dinner and breakfast the food is tasty and for my wife who is a vegetarian there is no specific dishes." Netherlands, Score:2, family.

"The food is tasteful but not plenty, vegetarian options are very poor." USA, Score:2, Solo.

“....Limited food varieties served during dinner....." Indonesia, Score: 2, Couple.

"....Food quality is good but for 5 star , variety of foods is inadequate." Turkey, Score:3, Business.

The capacity of restaurant/s: Noone and Mattila (2009) states that crowdedness is a negative factor for customers in perceiving the quality of restaurants. According to Toktassynova \& Akbaba (2017) crowded service environment take the great portion (82.1\%) of negative reviews in their study. Similarly, the capacity of restaurant/s is a dissatisfactory factor for thermal hotel customers', too (542 of 1,368). The following reviews depict it clearly.

"....Buffet: chicken and chips were OK, great salad selection, but restaurant was very crowded with group tours...." China, Score:2, Friends.

"The buffet hall is huge but it got messy with crowds, some food strewn on the floor." Spain, Score: 3, family.

"...Buffet was crowded with people, pushing and shoving to get a crack at what was mostly mediocre food." USA, Score:2, Solo.

"They do not re-set the tables at breakfast, so when my daughter and I came down at 8:30am after most of the big tour buses had gone we could not find a clean place to sit." Argentina, Score:2, Family.

"restaurant is small. most of the tables are for big groups that is already reserved by the waiters." Italy, Score:1, Couple. 
Freshness of food: There is an increasing tendency towards consumption of fresh F\&B by contemporary consumers (Melia, 2011). This situation makes the consumer more sensitive to healthy and fresh food. It is a fact that, if tourists feel distrustful about healthiness or freshness of food, that reduces the satisfaction of F\&B services (Hwang \& Lorenzon, 2008). A few of the 412 (30.1\%) negative comments about freshness of food can be found below.

"Breakfast served comes with very limited choice, no fresh fruits." N.A., Score:1, Family. "The dinner was cold, and after complaining about it and asking for new food, they took our plates, and literally microwaved it for us." Germany, Score:1, Couple.

"breakfast is insufficient, no muesli, no fresh fruit juice, no fruits, no milk." England, Score: 3, Friend.

"Food in the buffet was not inspiring or fresh." Australia, Score:2, Solo.

"The food was cold and not fresh. However, you have to pay extra for everything, even for water....." Canada, Score:1, Couple.

\section{One-way ANOVA analysis}

For the purposes of the study, one-way ANOVA was performed to determine whether satisfaction levels of $\mathrm{F} \& \mathrm{~B}$ service has an affect on overall hotel performance. As mentioned in the previous sections, comments were divided into 4 categories but for the one-way ANOVA analysis, only three categories (negative, neutral and positive review) were taken into account to get a clear picture of comparison between review categories and overall hotel scores. Firstly, the homogeneity of the variance was checked by Levene's test in order to identify the requirements for ANOVA (Levene $=13.142 ; \mathrm{p}=0.068$ ). Then, One-way ANOVA was performed with hotel score as the dependent variable and review group as the fixed factor. In the cases where significant results have been obtained in ANOVA, Least Significant Difference (LSD) was applied to identify where differences lie between categories on hotel performance $(\alpha=0.05)$.

Table 5 ANOVA results

\begin{tabular}{|c|c|c|c|c|c|c|c|c|c|}
\hline $\begin{array}{l}\text { Dependent } \\
\text { Variable }\end{array}$ & $\begin{array}{l}\text { Factor } \\
\text { Variable }\end{array}$ & Mean* & SD & $\mathbf{n}$ & $\begin{array}{c}\text { Sum of } \\
\text { Squares }\end{array}$ & df & $\begin{array}{c}\text { Mean } \\
\text { Square }\end{array}$ & $\mathbf{F}$ & Sig. \\
\hline \multirow{3}{*}{ Hotel Score } & Negative & 2.341 & 1.025 & 1,013 & & & & & \\
\hline & Neutral & 3.476 & .921 & 355 & & & & & \\
\hline & Positive & 4.434 & .712 & 1,401 & & & & & \\
\hline \multicolumn{2}{|c|}{ Between Groups } & & & & $2,575.96$ & 2 & $1,287.98$ & 1717.3 & .000 \\
\hline \multicolumn{2}{|c|}{ Within Groups } & & & & $2,074.51$ & 2,766 & .75 & & \\
\hline \multicolumn{2}{|c|}{ Total } & & & & $4,650.47$ & 2,768 & & & \\
\hline
\end{tabular}


Results (see Table 5) showed that there are significant differences $(F=1717.3 ; p<0.000)$ in relation to review categories on hotel scores. According to this, the mean hotel scores of the negative reviews are at the lowest level (2.34) and it is followed by neutral reviews (3.47) and positive reviews (4.43) respectively. Moreover, the post hoc LSD test (Table 6) showed that all the review categories were significantly $(\mathrm{p}<0.000)$ different from each other. Most researchers have examined the impact of F\&B services on customer loyalty and customer satisfaction in hotel businesses and satisfaction with $\mathrm{F} \& \mathrm{~B}$ services has been directly related to hotel satisfaction (Alén et al., 2006; Kundampully \& Suhartanto, 2000; Acharya, Sengupta, \& Mishra, 2011). Similarly, in this study, in a manner of conforming to descriptive statistics of review categories and ANOVA results, there is a strong relationship between customers' satisfaction on F\&B services and overall thermal hotel satisfaction.

Table 6 Multiple comparisons (LSD).

\begin{tabular}{|c|c|c|c|c|c|}
\hline & (I) Group & (J) Group & $\begin{array}{c}\text { Mean } \\
\text { Difference (I-J) }\end{array}$ & $\begin{array}{l}\text { Std. } \\
\text { Error }\end{array}$ & Sig. \\
\hline \multirow{6}{*}{ Hotel Score } & \multirow[t]{2}{*}{ Negative } & Neutral & $-1.134^{*}$ & .053 & .000 \\
\hline & & Positive & $-2.092 *$ & .035 & .000 \\
\hline & \multirow[t]{2}{*}{ Neutral } & Negative & $1.134 *$ & .053 & .000 \\
\hline & & Positive & $-.957 *$ & .051 & .000 \\
\hline & \multirow[t]{2}{*}{ Positive } & Negative & $2.092 *$ & .035 & .000 \\
\hline & & Neutral & $.957^{*}$ & .051 & .000 \\
\hline
\end{tabular}

* The mean difference is significant at the 0.05 level.

\section{CONCLUSION}

F\&B services are one of the most important parts of tourism industry. In addition, the F\&B department is one of the most revenue-generating departments, as well as positively affecting customer loyalty and customer satisfaction in the hotel. This also applies to thermal hotels. Therefore, understanding visitor expectations and perceptions of F\&B services is one of the critical factors in achieving customer satisfaction in the thermal hotel. This study contributes to tourism literature by revealing the satisfactory/dissatisfactory factors of F\&B in thermal hotel visitors of Denizli, Turkey.

Unlike many other studies, the current research investigated the satisfactory and dissatisfactory factors of $F \& B$ services in the thermal hotel by examining the reviews of guests in TripAdvisor. In the study, firstly, the F\&B related reviews were divided into three categories (negative, neutral and positive), then the comments in the neutral categories were 
included in the positive and negative categories according to their contents. After the content analysis of the positive and negative reviews, there are 4 satisfied and 4 dissatisfied main factors identified. The satisfactory factors of F\&B services in the thermal hotels were found as; taste of food, employees, quality of food and activities in the restaurants (e.g. live music). On the other hand, the main factors where the reviewers are dissatisfied were determined as; high price, variety of food (lack of vegetarian menu, steak menu etc.), capacity for restaurants (i.e. crowdedness in restaurants) and freshness of food. The results of this study are similar to the study of Giritlioglu et al., (2014). Accordingly, thermal hotel customers pay attention to tangible features of F\&B services in both studies. Therefore, thermal hotel managers should pay particular attention to tangible characteristics of F\&B services. These results contribute to increasing managerial success by guiding hotel managers with limited resources to which areas resources should be transferred. Moreover, the present study revealed the direct relationship between catering services and overall hotel satisfaction. This proves that F\&B services are vital for the thermal hotel.

This study has some limitations that should be considered in the interpretation of the study. First of all, the current study is based on textual data collected from TripAdvisor, so some of the necessary details like demographic or tripographic information are lacked (Berezan et al., 2015). Future research, particularly for the case studies, may use reviews from other online sites and additional methods, to validate and extend these findings. Additionally, the current study only used the reviews of the tourists who stayed in the thermal hotels in Denizli, Turkey. Therefore, findings of F\&B services in the thermal hotels cannot be generalised. In future research, data can be collected from different thermal cities to conducting a comparative analysis of competing cities.

\section{REFERENCES}

Abbey, K. L., Wright, O. R. L., \& Capra, S. (2015). Menu Planning in Residential Aged CareThe Level of Choice and Quality of Planning of Meals Available to Residents. Nutrients, 7(9), 7580-7592.

Acharya, S. B., Sengupta , P. P., \& Mishra , R. (2011). Exploring customer loyalty: A study on fast food outlines in the city of Chennai. International Journal of Multidisciplinary Research, 1(4), 175-183.

Alén, M.E., Fraiz, A.J., \& Rufin, R. (2006). Analysis of health spa customers' expectations and perceptions: the case of Spanish establishments. Polytechnic Studies Review, 3 $(5 / 6), 245-262$.

Andaleeb, S. S., \& Conway, C. (2006). Customer satisfaction in the restaurant industry: an examination of the transaction-specific model. Journal of Services Marketing, 20 (1), 311. 
Araujo, R. T. S. A., Paiva, T., Ribeiro, M. P., \& Coutinho, P. (2015). Innovation in Thermalism: An Example in Beira Interior Region of Portugal. In M. Peris-Ortiz and J. Álvarez-García (eds.). Health and Wellness Tourism Emergence of a New Market Segment (pp.165-180). London: Springer.

Azakli, H. S. (2012). Institutional and spatial aspects of thermal tourism in Turkey: Nevsehir kozakli thermal tourism center. (MSc Thesis, Middle East Technical University), Retrived February 8, 2017 from: http://citeseerx.ist.psu.edu/viewdoc/download;jsessionid=D1662A54253F4BBFBFF580 2343D999B4?doi=10.1.1.633.9550\&rep=rep1\&type $=$ pdf

Bakucz, M. \& Flink, A. (2012). Competitiveness and Potential in Spas and Health Resorts in Some Central European Regions: Conclusions from on-going research in South Transdanubia, Hungar." Networks regions and cities [in] times of fragmentation: developing smart, sustainable and inclusive places: Annual European Conference, 13 May - 16th May 2012, Delft University of Technology, Delft, Netherlands.

Basil, M. \& Basil, D.Z. (2009). Reflections of ultra-fine dining experiences. In Lindgreen, A., Vanhamme, J. and Beverland, M.B. (Eds), Memorable Customer Experiences: A Research Anthology (pp. 135-147). Surrey: Gower.

Berezan, O., Raab, C., Tanford, S., \& Kim, Y.S. (2015). Evaluating loyalty constructs among hotel reward program members using eWOM. Journal of Hospitality \& Tourism Research, 39 (2), 198-224.

Bigné, J. E., Mattila, A. S., \& Andreu, L. (2008). The impact of experiential consumption cognitions and emotions on behavioral intentions. Journal of Services Marketing, 22(4), 303-315.

Boekstein, M. (2014). From illness to wellness-has thermal spring health tourism reached a new turning point? African Journal of Hospitality, Tourism and Leisure. 3(2), 1-11.

Browning, V., So, K. K. F., \& Sparks, B. (2013). The influence of online reviews on consumers' attributions of service quality and control for service standards in hotels. Journal of Travel \& Tourism Marketing, 30 (1-2), 23-40.

Chua, B., Lee, S., Goh, B., \& Han, H. (2015). Impacts of cruise service quality and price on vacationers' cruise experience: moderating role of price sensitivity. International. Journal of Hospitality Management, 44, 131- 145.

Clark, J. E. (1998). Taste and flavour: their importance in food choice and acceptance, Proceedings of the Nutrition Society, 57, 639-643.

Costa, C., Quintela, J., \& Mendes, J. (2015). Health and Wellness Tourism: A Strategic Plan for Tourism and Thermalism Valorization of São Pedro do Sul. In M. Peris-Ortiz and J. Álvarez-García (eds.) Health and Wellness Tourism Emergence of a New Market Segment (pp.63-76). London: Springer.

Driscoll, D. L., Appiah-Yeboah, A., Salib, P., \& Rupert, D. J. (2007). Merging qualitative and quantitative data in mixed methods research: how to and why not. Ecological and Environmental Anthropology, 3(1), 19-28.

Emir, O., \& Paşaoğlu, D. (2013). Impact of the service quality of Turkish thermal hotel enterprises on customer loyalty. Balikesir University The Journal of Social Sciences Institute. 16(30), 185-202.

Erfurt-Cooper, P. \& Cooper, M. (2009). Health and Wellness Tourism - Spas and Hot Springs. Bristol: Channel View.

Fontanari, F., \& Kern, A. (2003). The "Comparative Analysis of Spas" - An instrument for the re-positioning of spas in the context of competition in spa and health tourism. Tourism Review, 58 (3):20 - 28. 
Gagić, S., Tešanović, D., \& Jovičić, A. (2013). The vital components of restaurant quality that affect guest satisfaction. TURIZAM, 17(4), 166-176.

Giritlioğlu, İ. (2013). Yiyecek İçecek Bölümlerinde İşgörenlerin ve Müşterilerin Hizmet Kalitesi Beklenti ve Algıları: Termal Otellerde Bir Araştırma, Balıkesir Üniversitesi Sosyal Bilimler Enstitüsü Dergisi, 16 (29), 329-355.

Giritlioglu, I., Jones, E., \& Avcikurt, C. (2014). Measuring food and beverage service quality in spa hotels: A case study in Balıkesir, Turkey. International Journal of Contemporary Hospitality Management, 26 (2), 83-204.

Gligorijevic, Z., \& Petrovic, J. (2010). The position of Niska Banja (Nis Spa) in Serbian spa tourism. Economics and Organization, 17 (3), 309-317.

Global Wellness Institute. (2017). Global Wellness Economy Monitor, January 2017. The Global Wellness Institute. Retrieved May 12, 2017, from https://www.globalwellnessinstitute.org/industry-research.

Gould-Williams, J. (1999). The impact of employee performance cues on guest loyalty, perceived value and service quality. The Service Industries Journal, 19(3), 97-118.

Gretzel, U., \& Yoo, K.H. (2008). Use and Impact of Online Travel Reviews. In: O'Connor P., Höpken W., Gretzel U. (eds), Information and Communication Technologies in Tourism (pp. 35-46). Vienna: Springer.

Gu, B., \& Ye, Q. (2014). First step in social media-measuring the influence of online management responses on customer satisfaction. Production and Opererations Management, 23 (4), 570-582.

Harmsworth, S. (2004). The latest trends and developments in health and spa market. Insights, $15,173-178$.

Hill, N., Roshe, G., \& Allen, R. (2007). Customer Satisfaction: The Customer Experience Through the Customer's Eyes. London: Cogent.

Hudson, S., \& Li, X. (2012). Domestic medical tourism: a neglected dimension of medical tourism research. Journal of Hospitality Marketing and Management, 21, (3), 227 -246.

Hwang, J., \& Lorenzon, C.L. (2008). Effective nutrition labeling of restaurant menu and pricing of healthy menu. Journal of Foodservice, 19, 270-276.

Kaya, O. (2017). Turistlerin Kruvaziyer Gemileri Yiyecek ve İçecek Hizmetlerinden Beklenti ve Performans Düzeylerine İlişkin Bir Araștırma. Jounal of Tourism and Gastronomy Studies, 5(2), 22-38.

Kelly, C. (2012). Wellness tourism: retreat visitor motivations and experiences. Tourism Recreation Research, 37(3): 205-213.

Kervankıran, İ. (2016). Between Traditional and Modern: Thermal Tourism in Turkey. In Egresi I. (eds) Alternative Tourism in Turkey (pp.109-124). Cham: Springer.

Keung, S. W. C. (2000). Tourist' perceptions of hotel frontline employees' questionable job related behaviour. Tourism Management, 16(1),39-63.

Kilic, F. C. (2016). Geothermal Energy in Turkey. Energy and Environment, 1-17.

Kovács, E., Bacsi, Z., \& Lőke, Z. (2012). Key success factor of spas - interviews with leaders in three spa towns in Hungary. Deturope, 4(1):5-22.

Kundampully, J., \& Suhartanto, D. (2000). Customer loyalty in the hotel industry: the roll of customer satisfaction and image. International Journal of Contemporary Hospitality Management, 12(6), 346-351.

Kuo, C.M. (2007). The importance of hotel employee service attitude and the satisfaction of international tourists. The Service Industries Journal, 27 (8), 1073-1085.

Lagrosen, Y., \& Lagrosen, S. (2016). Customer perceptions of quality - a study in the SPA industry. European Business Review, 28 (6): 657-675.

Lamoreaux, P.E. (2005). History and classification of springs. Geological Society of America Abstract with Programs, 37(7): 324. 
Lebe, S. S. (2006). European spa world. Journal of Quality Assurance in Hospitality \& Tourism, 7 (1-2): 137-146.

Liu, Y., \& Jang, S. (2009). Perceptions of Chinese restaurants in the U.S.: What affects customer satisfaction and behavioral intentions? International Journal of Hospitality Management, 28: 338-348.

Liu, B., Kim, H., \& Penning-Gray, L. (2015). Responding to bed bug crisis in social media. International Journal of Hospitality Management, 47 (May), 76-84.

Mainil, T, Eijgelaar, E, Klijs, J, Nawijn, J., \& Peeters, P. (2017). Research for TRAN Committee - Health tourism in the EU: a general investigation. European Parliament, Policy Department for Structural and Cohesion Policies, Brussels.

Mauri, A. G., \& Minazzi, R. (2013). Web reviews influence on expectations and purchasing intentions of hotel potential consumers. International Journal of Hospitality Management, 34, 99-107.

Mela, D. (1999). Food choice and intake: the human factor. Proceedings of the Nutrition Society, 58, 513-521.

Melia, D. (2011). Trends in the food and beverage sector of the hospitality industry. EuroCHRIE Conference, Dubrovnik, Croatia.

The Ministry of Culture and Tourism of the Republic of Turkey. (2017). Numbers of touristic facilities in Turkey. Retrieved April 11, 2017, from: http://yigm.kulturturizm.gov.tr/TR,9579/turizm-tesisleri.html

The Ministry of Energy and Natural Resources of Turkey. (2018). Geothermal. Retrieved June 22, 2018, from http://www.enerji.gov.tr/en-US/Pages/Geothermal

Noone, B. M., \& Mattila, A. S. (2009). Consumer reaction to crowding for extended service encounters. Managing Service Quality: An International Journal, 19 (1), 31-41.

Oliver, R. L. (1980). A Cognitive model of the antecedent and consequences of satisfaction decisions. Journal of Marketing Research, 17 (4), 460-469.

Rahman, M., Kalam, A., Rahman, M., \& Abdullah, M. (2012). The influence of service quality and price on customer satisfaction: An empirical study on restaurant services in Khulna division. Research Journal of Finance and Accounting, 3(4), 8-15.

Saar, M. (2010). Cultural differences in spa tourism and the expectations of Finnish spa goers (MSc thesis). Retrieved January 15, 2017 from: http://www.theseus.fi/handle/10024/10936

Saraiva, M., Cid, M., \& Baião, C. (2011). The Degree of Customer Satisfaction in University Restaurants: The Case of the University of Evora in Portugal. Proceedings of EDULEARN11 Conference, 4-6 July 2011, Barcelona, Spain.

Schuckert, M., Lu, X., \& Law, R. (2015). A segmentation of online reviews by language groups: How English and non-English speakers rate hotels differently. International Journal of Hospitality Management, 48 (July), 143-149.

Smith, M. K., \& Puczkó, L. (2009). Health and Wellness Tourism. Oxfod: ButterworthHeinemann.

Stará, J., \& Peterson, C. (2017) Understanding the concept of wellness for the future of the tourism industry: a literature review. Journal of Tourism and Services, 7 (14), 18-29.

Stepchenkova, S., \& Zhan, F. (2013). Visual destination images of Peru: Comparative content analysis of DMO and user-generated photography. Tourism Management, 36, 590-601.

Teddlie, C., \& Tashakkori, A. (2009), Foundations of mixed methods research: Integrating quantitative and qualitative approaches in the social and behavioral sciences, Thousand Oaks, CA: Sage.

Trip Advisor. (2017). About Trip advisor. Retrieved September 23, 2017, from: https://tripadvisor.mediaroom.com/tr-about-us 
Toktassynova, Z., \& Akbaba, A. (2017) Content analysis of on-line booking platform reviews over a restaurant: a case of pizza locale in Izmir. International Journal of Contemporary Tourism Research, 2, 29-35.

Türksoy, A., \& Türksoy, S. S. (2010). Termal Turizmin Geliştirilmesi Kapsamında Çeşme İlçesi Termal Kaynaklarının Değerlendirilmesi. Ege Akademik Bakış, 10 (2), 701-726.

UNWTO. (2017). UNWTO Tourism Highlights 2017 Edition. Retrieved May 9, 2017, from: https://www.e-unwto.org/doi/pdf/10.18111/9789284419029

Wang, S., \& Hung, K. (2015). Customer perceptions of critical success factors for guest houses. International Journal of Hospitality Management. 48, 92-101.

Winstead, K. F. (2000). Service behaviors that lead to satisfied customers. European Journal of Marketing, 34(3-4), 399-417.

Zengin, B., \& Eker, N. (2016). Sakarya ili termal turizm potansiyelinin değerlendirilmesi. Kastamonu Üniversitesi İktisadi ve İdari Bilimler Fakültesi Dergisi. 13 (Temmuz), 165181.

Zhou, L., Ye, S., Pearce, P. L., \& Wu, M.-Y. (2014). Refreshing hotel satisfaction studies by reconfiguring customer review data. International Journal of Hospitality Management, $38,1-10$.

Zollo, A, Simonetti, B., Salsano, V., \& Rueda-Armengot, C. (2015). Promotion and Marketing: Marketing Strategies, Italy, Regional Development. In M. Peris-Ortiz and J. Álvarez-García (eds.) Health and Wellness Tourism Emergence of a New Market Segment (pp.63-76). London: Springer. 